\title{
The Next WTO Round on Agriculture and EU Enlargement: Pressures for Reforms in the EU Common Agricultural Policy
}

\author{
Ellen Huan-Niemi \& Jyrki Niemi \\ MTT Agrifood Research Finland \\ PL 3 (Luutnantintie 13) \\ 00411 Helsinki \\ ellen.huan-niemi@mtt.fi \\ jyrki.niemi@mtt.fi
}

\section{Introduction}

Negotiations on agricultural trade liberalisation were launched at the World Trade Organisation (WTO) in March 2000, following on agreements made in 1994 under the Uruguay Round. Member countries of the WTO have agreed to continue the ongoing agricultural negotiations on the basis of Article 20 of the Uruguay Round Agreement on Agriculture (URAA). Negotiating proposals have been submitted by member countries to the WTO, paving the way for the future trade round launched in Doha, Qatar. The Ministerial Declaration on November 2001 in Doha and future negotiations will influence the shape and dynamics of the comprehensive trade round.

Different interest groups in the WTO have diverse proposals for the future agreement on agriculture. For instance, the Cairns Group has proposed for phased elimination of export subsidies and amber box support with a 50 percent cut in the first implementation year of the Next WTO Round. On the other hand, the EU has proposed that tariff and farm subsidy cuts to be along the same lines as in the Uruguay Round. It is uncertain what is going to be the outcome of the Next WTO Round, but certain assumptions can be put in place for projecting the impacts of the Next WTO Round.

This study will focus on the impacts of the projected future WTO commitments on the EU's dairy sector, meat sector, and cereals sector. In addition, the impacts of the prospective EU enlargement by including the ten Central and Eastern European (CEE) countries are assessed in relation to the future WTO commitments for export subsidies and domestic support.

\section{Methodology}

The reduction in commitments for the Next WTO Round is assumed to be along the same lines as in the Uruguay Round with further 36 percent reduction in export subsidy expenditure, 21 percent reduction in the volume of subsidised export, 36 percent or 20 percent reduction in standard tariffs, and 20 percent reduction in the Aggregate Measure of Support (AMS). The base year for reduction in commitments is 2003/2004, which is a continuance of the Uruguay Round's 2000/2001 level. It is assumed that there will be a three-year lapse before the start of the Next WTO Round on agriculture because the on-going WTO negotiations process is assumed to continue for 3 years after the end of the Uruguay Round in marketing year 2000/2001. The Next WTO Round is assumed to begin in marketing year 2004/2005 and end in marketing year 2009/2010 over a six-year implementation period.

The EU notifications to the WTO are used as a base for the export subsidy and domestic support projections (WTO Notifications). Average subsidy per ton for marketing year 1998/1999 is used for the projection of the actual export subsidy expenditure (1998/1999 average subsidy per ton multiplied by the total subsidised exports) for all commodities. The EU total exports figures for agricultural commodities are based on FAPRI (2000) or OECD (2000) projections. The production figures for the commodities used in the calculation of the AMS projections are based on the European Commission's "Prospects for agricultural markets 2000-2007" (CEC 2000).

The world market prices for agricultural commodities are based on FAPRI (2000) projections. The market access or level of protection for EU agricultural commodities have two different scenarios in order to show the effects of a strong and weak Euro. The projected world market prices are directly influenced by the strength of the Euro denominated in US dollar: the rate for the "strong Euro" scenario is USD 1.20/Euro and the rate for the "weak Euro" scenario is USD 0.80/Euro. The world 
market prices are on the basis of CIF prices instead of FOB prices. The average freight and insurance calculations for the CIF prices of the agricultural commodities are based on FAOSTAT (2000) database.

Under EU enlargement, it is assumed that the first group (Luxembourg Group) of CEE countries to join the EU are Poland, Hungary, Czech Republic, Slovenia, and Estonia and the second group (Helsinki Group) are Latvia, Lithuania, Slovakia, Bulgaria, and Romania. The Luxembourg Group is assumed to join the EU in year 2005 and the Helsinki Group in year 2008. It is assumed that EU membership for the CEE countries does not affect agricultural production and exports of the new member states. Thereby, market balance in the EU-25 market is maintained. It is further assumed that production quotas will be imposed on milk production in the CEE countries. The production quotas will correspond to the 1999 production level for milk in the CEE countries. In the projections, the CEE countries' net exports (or imports) are added to the EU-15 total exports. Intra-trade within the CEE countries and intra-trade between the CEE countries and EU are excluded from the CEE countries' net exports calculations.

\section{Results}

Under the EU-15 scenario in the Next WTO Round, the export subsidy commitments for the dairy sector will be binding for all products (skim milk powder, cheese, other milk products) with the exception of butter (Graph 1). In the meat sector, the export subsidy commitments will be binding for pigmeat and poultry meat, but not binding for beef. In the cereals sector, the export subsidy commitments will be binding for both wheat and coarse grains, but only for quantity commitments. There is a lot of slack in the budgetary commitments for wheat and coarse grains.

Under the EU-25 scenario in the Next WTO Round, the export subsidy commitments for the dairy sector will continue to be binding for all products with the exception of butter. EU enlargement will put additional pressure on the export subsidy commitments for skim milk powder, but will ease the binding quantity commitments for cheese, and butter exports can continue to be fully subsidised. In the meat sector, EU enlargement will somewhat ease the binding quantity commitments for pigmeat, but less export subsidy per ton may be utilised. There will be no additional pressure on the export subsidy commitments for beef and pressure on the export subsidy commitments for poultry meat will ease.

The CEE countries' tariff systems will be unified with the tariff system of the EU after accession to the EU. As a consequence, the EU-15 scenarios for market access will be the same for EU-25 scenarios. Under the scenario of a strong Euro (USD 1.20/Euro) and further tariff reductions in the Next WTO Round, the EU will face border protection problems for butter starting from marketing year 2002/2003. The 15 percent cut in butter support price (Agenda 2000 Dairy Reforms from year 2005 to 2007) may not be steep enough to cover a 36 percent cut in tariff in this case. Nonetheless, the EU can invoke the Special Safeguard Provisions (trigger price) under the URAA that allow additional duties to be imposed in the case of low world market prices. The additional duties imposed by invoking the trigger price mechanism are just enough to safeguard the border protection for butter until year 2009/2010 (Graph 2). In contrast, the EU will be able to maintain its border protection for skim milk powder, beef, pigmeat, poultry meat, wheat, and coarse grains (barley \& maize) even if the Euro appreciates to the level of USD 1.20/Euro. Border protection problems will definitely not arise for all the sectors (dairy, meat, cereals) under a weak Euro (USD 0.80/Euro) and further tariff reductions.

In the Next WTO Round, the domestic support projections for the EU-15 and EU-25 scenarios indicate that the EU will not face any problems in staying within the Aggregate Measure of Support (AMS) commitments. The amber box is well beneath the AMS commitments whereby there is a shift from amber box support payments to blue box support payments. The shift in payments is due to the effect of Agenda 2000 Reforms in the Common Agriculture Policy. The reduction in support prices for cereals, beef, and dairy products are being compensated through the direct payments of the blue box. If the blue box payments are included in the AMS calculations, the EU-15 scenario may still be able to stay within the AMS commitments, but the enlarged EU will certainly risk breaching the future AMS commitments (Graph 3). It is uncertain whether the Peace Clause that exempts the blue box payments from reduction will continue to the Next WTO Round. As a consequence, the EU will breach the domestic support commitments if the CAP prices and support mechanisms (direct payments) are applied to the CEE countries. 


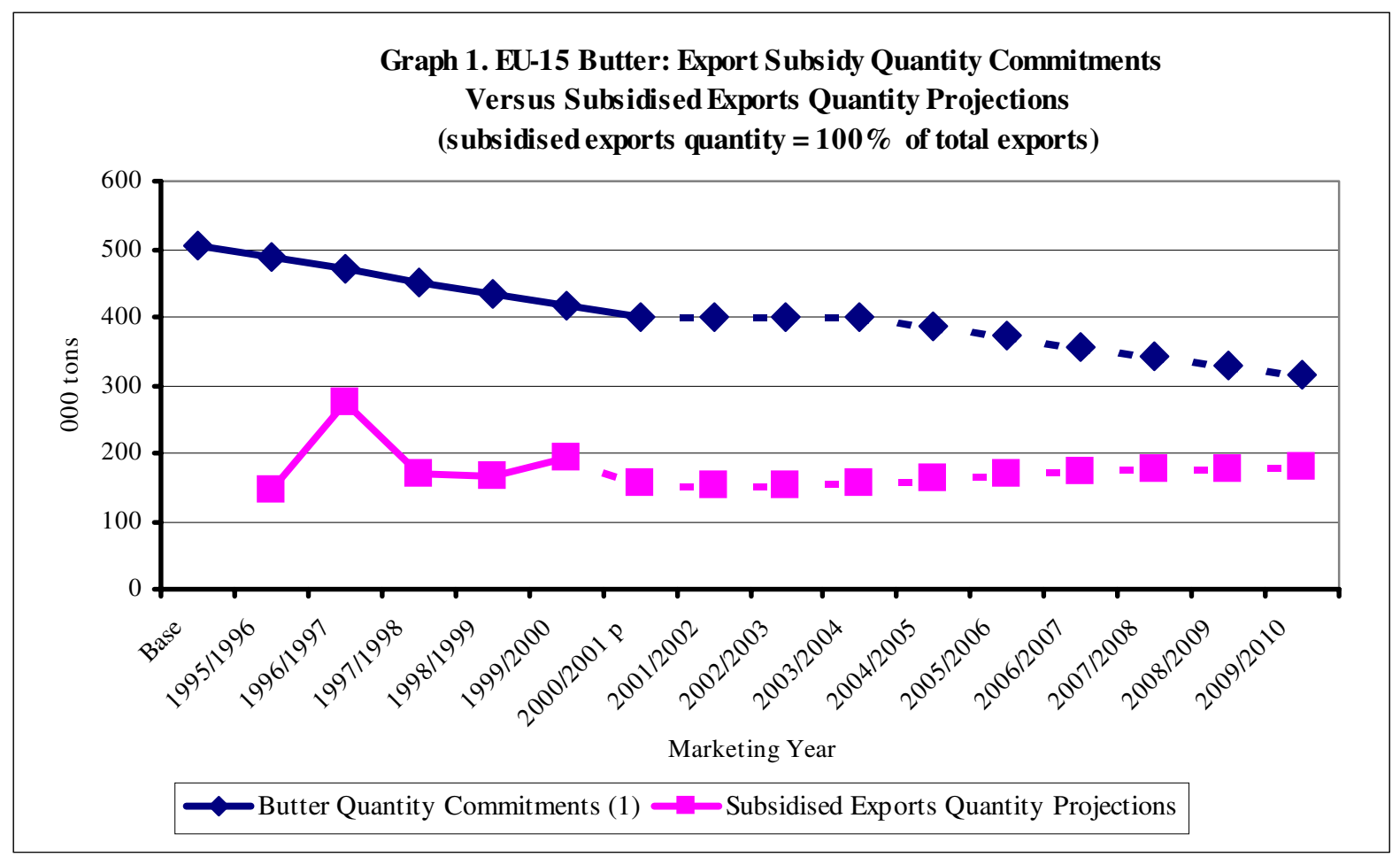

(1) Butter Quantity Commitments are further reduced by $21 \%$

p: FAPRI 2000 Outlook of EU butter exports (subsidised exports quantity $=100 \%$ of total exports)

Source: FAPRI 2000, WTO Notifications, Huan-Niemi \& Niemi 2001.

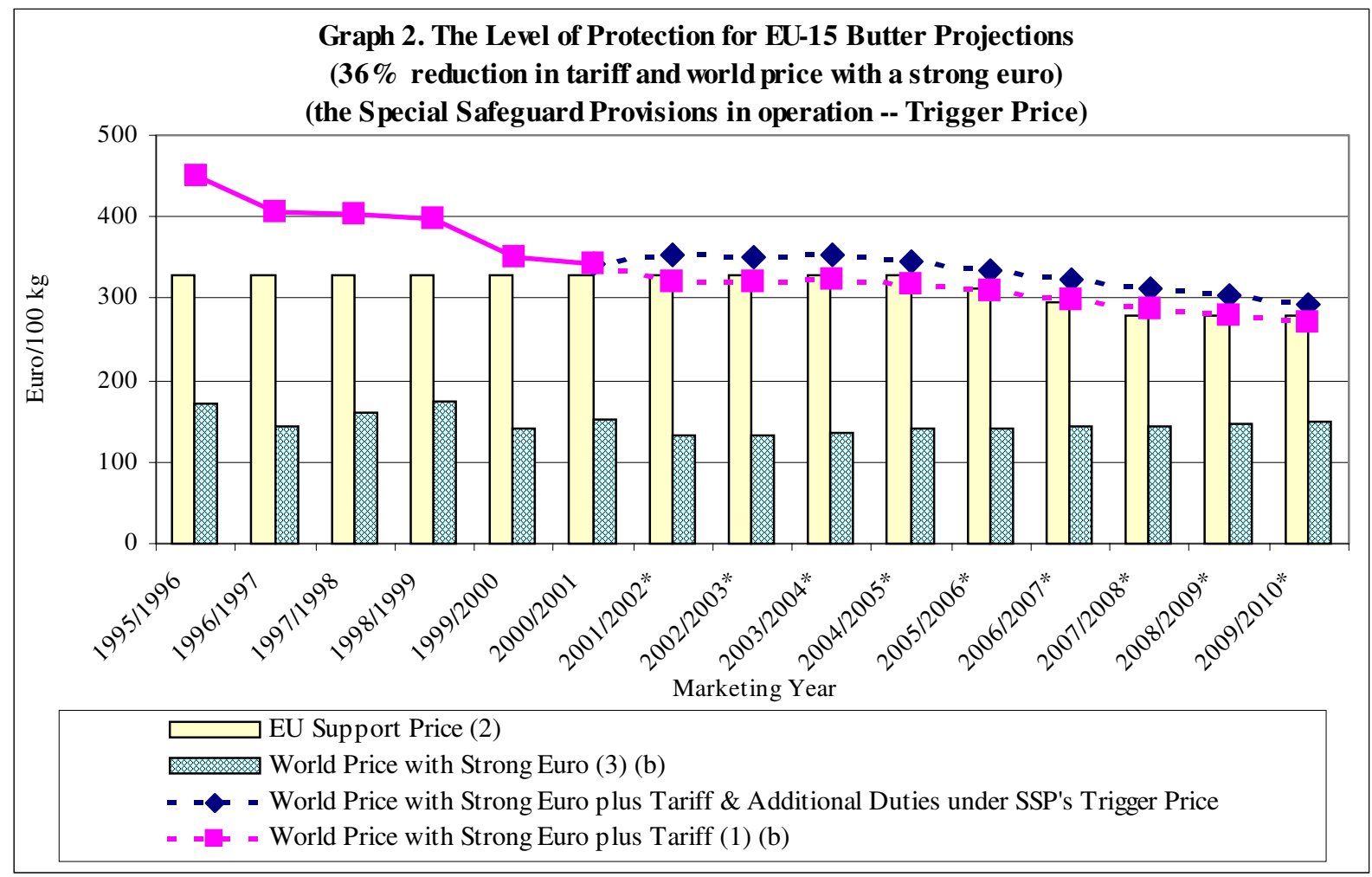

(1) Standard tariff is further reduced by $36 \%$ for butter

(2) Agenda 2000 Reforms that include a 15\% butter support price cut in three steps from year 2005 to 2007

(3) World Price is based on butter, 82\% butterfat, Northern Europe

(a) World Price projections are based on a weak Euro -- 1 Euro $=0.80$ USD

(b) World Price projections are based on a strong Euro -- 1 Euro $=1.20$ USD

* The additional duties imposed under the Special Safeguard Provisions are calculated from marketing year 2001/2002 onwards

Source: FAPRI 2000, Huan-Niemi \& Niemi 2001. 


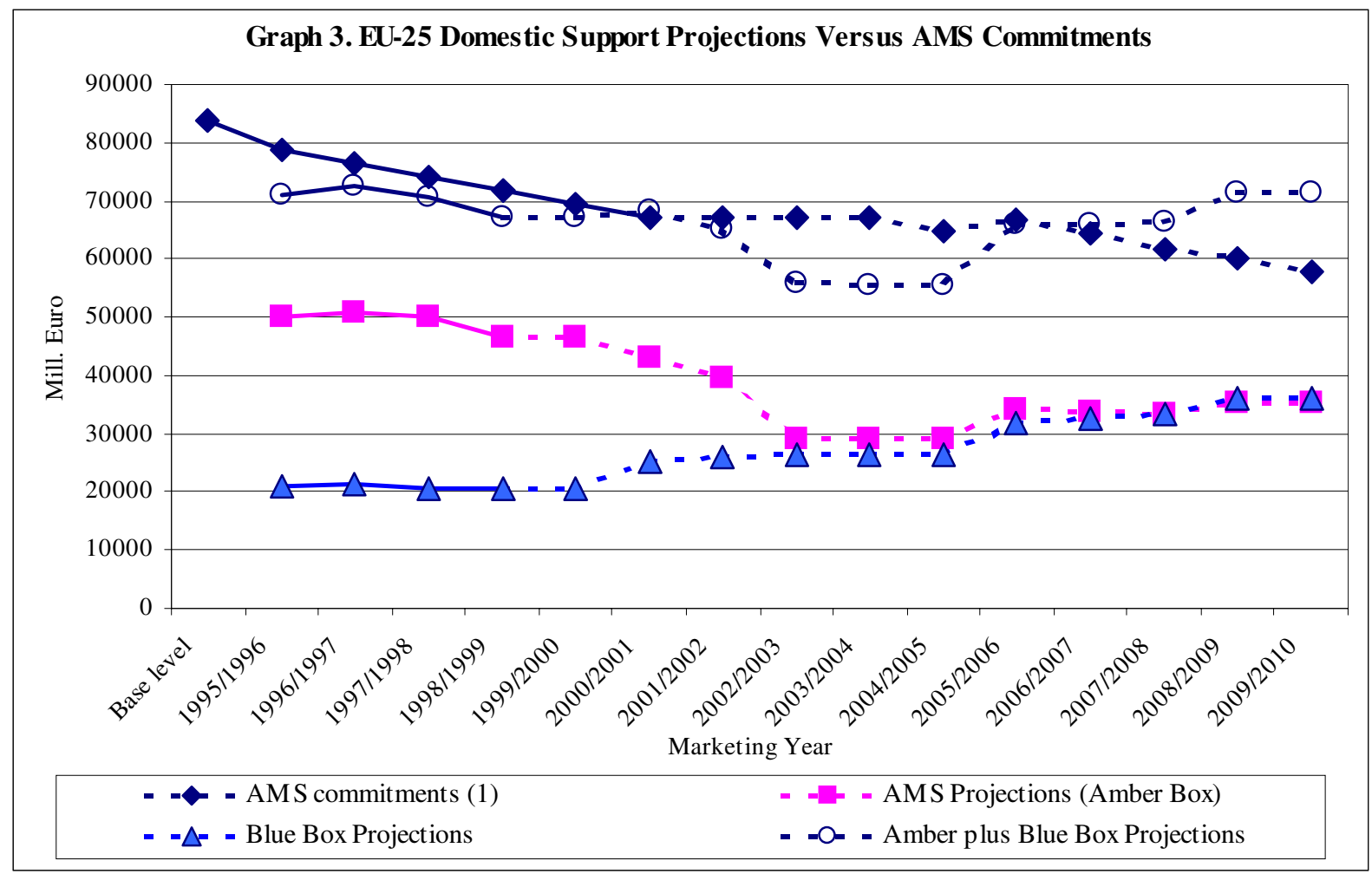

(1) The Aggregate Measure of Support (AMS) Commitments are further reduced by 20\% from year 2003/2004 Source: WTO Notifications, Peltoniemi, A. 2001, Huan-Niemi \& Niemi 2001.

\section{Conclusions}

The Next WTO Round will not be a threat to the dairy, meat, and cereals sector if the Next WTO Round is going to be along the same lines as the Uruguay Round and the Euro remains to be weak or below parity with the US dollar. Although, some mild reforms are needed in the EU Common Agriculture Policy in order to stay within some of the binding export subsidy commitments. The current weakness of the Euro has allowed the EU to have a lot of "breathing space" in the agricultural commodity markets. However, EU eastwards enlargement will put additional pressure on some of the commodities. As a result, the EU may risk breaching the future WTO commitments for export subsidy and domestic support. Actually, the future threats in the Next WTO Round will be complete elimination of export subsidy, steeper reductions in tariffs (more than 36\%) or elimination of tariffs (for example: "everything but arms" deal with the least developed countries), the lapse of the Peace Clause, and the Euro strengthening to above the parity level with the US dollar. These future threats may inadvertently force the EU to drastically reform the Common Agricultural Policy.

\section{References}

CEC 2000. Prospects for agricultural markets 2000-2007. Commission of the European Communities, Directorate-General for Agriculture, Brussels.

FAOSTAT 2000. Food and Agriculture Organisation of the United Nations Statistical Databases. Updated 22.12.2000. Available at http://apps.fao.org.

FAPRI 2000. World Agricultural Outlook 2000, Food and Agricultural Policy Research Institute. Iowa State University - University of Missouri-Columbia.

Huan-Niemi, E. \& Niemi, J. 2001. The Next WTO Round on Agriculture and EU Enlargement: Pressures for reforms in the EU Common Agricultural Policy, MTT Agrifood Research Finland, Economic Research (MTTL), Working Papers 22/2001.

OECD 2000. OECD Agricultural Outlook 2000-2005. Publication Service of the OECD, 2000, Paris.

Peltoniemi, A. 2001. EU:n laajentuminen KIE-maihin: maatalouden suorat tuet, jäsenvaltiokohtaiset määrärahat, luonnonhaittakorvaukset ja ympäristötuki - suuntaa antava laskelma. Economic Research, MTT Research Finland. Mimeogr. 14.05.2001.

WTO Notifications. World Trade Organisation. Available at www.wto.org. G/AG/N/EEC. 